\title{
Chapter 2 \\ The Pedagogical Frameworks Adopted by Monash University Library
}

\author{
Lynette Torres and Barbara Yazbeck
}

\begin{abstract}
This chapter describes three of the pedagogical frameworks that comprise the Models of Engaged Learning and Teaching (Willison, J. (2017). The Models of Engaged Learning and Teaching (MELT); Willison, J. (2020). The models of engaged learning and teaching: Connecting sophisticated thinking from early childhood to PhD. Springer). Monash University Library (MUL) adopted the MELT to underpin its teaching practice and guide library-faculty teaching collaborations. The MELT include the Research Skill Development (RSD) framework (Willison, J., \& O'Regan, K. (2006/2018). Research skill development framework), the Work Skill Development (WSD) framework (Bandaranaike, S., \& Willison, J. (2009/2018). Revised by Monash University Library, 2019. Work skill development framework; Revised by Monash University Library 2019) and the Digital Skill Development (DSD) framework (Torres, L., McLeod, A., Yazbeck, B., Rayner, G., Skrbis, M., Yates, S., Dickson, N., \& Fulton, H. (2018). Digital skill development framework). The MELT have proved effective and adaptable in a range of disciplines and learning contexts by describing not only what students' research, work and digital skills are but how they can be explicitly developed as a critical part of learning. Successful application of these models has strengthened and maximised the effectiveness of library-faculty teaching collaborations. This has enabled the library to remain responsive to contemporary skill agendas and as such, catalysed transformative change by repositioning the Library as a key contributor to student learning.
\end{abstract}

\subsection{Background}

A core function of the university library is to connect students, academic staff and researchers with requisite information resources to support study and research purposes (Bryant et al., 2020). Although academic libraries are key figures in providing these critical services, the past two decades have seen significant evolutionary change in how libraries perceive their role and the contribution they make

L. Torres $(\bowtie) \cdot$ B. Yazbeck

Monash University, Clayton, Australia

e-mail: lynette.torres@monash.edu

(C) The Author(s) 2021

L. Torres et al. (eds.), Connecting the Library to the Curriculum,

https://doi.org/10.1007/978-981-16-3868-8_2 
to core university learning and teaching agendas. Deeply collaborative in nature, academic libraries have drawn on this characteristic to expand their educational role and align their information literacy (IL) skill expertise with student learning in the curriculum.

Motivating libraries to move (IL) more purposefully into the teaching space was prompted by a new focus on undergraduate research initiatives (Boyer Commission 1998), the advent of the library profession's Information Literacy Standards (ALA, 2000; CAUL 2001; ANZIIL 2004) and the introduction of University Graduate Attributes - outcome statements articulating the skills and attitudes graduating students should be able to demonstrate on completion of their studies (Oliver, 2013). A focus on students' skills signalled an opportunity for academic libraries to position themselves more firmly in the educational space. Hill et al. (2016) acknowledge the importance of students having gained a wide repertoire of skills from their studies which can include the following:

...critical thinking skills, such as intellectual curiosity, analytical reasoning, problem-solving and reflective judgement; effective communication; leadership and teamwork skills; research and inquiry skills; information literacy; digital literacy; personal attributes such as selfawareness, self-confidence, personal autonomy/self-reliance, flexibility and creativity; and personal values such as ethical, moral and social responsibility, integrity, and cross-cultural awareness (p. 156).

Such skills and attributes are considered both fundamental and critical for students to successfully undertake further study, gain employment, participate in and contribute positively to society (Barnett, 2000; Barrie, 2004; Bundy, 2004; Head et al., 2013). This has argued well for academic libraries to seize the opportunity, promote and link their information literacy expertise to the student learning journey to strengthen and maximise the library's contribution to student learning success.

\subsection{Positioning the Library in the Educational Space}

It is widely accepted that skills related to research coexist within knowledge making practices in the curriculum (Barnett \& Ceci, 2002; Brew, 2006, 2012; Healey \& Jenkins, 2009; Willison, 2012, 2020). As such, a strong call came from the library profession to champion information literacy and establish collaborative libraryfaculty teaching partnerships to facilitate access to the curriculum (Doskatsch, 2002; Peacock, 2001). However, as Doskatsch (2003) notes, connecting information literacy and research skill development to student learning can be challenging as 'success in fostering faculty-librarian collaboration depends on establishing common understanding and overcoming preconceptions and perceptions of such a relationship, and the external forces that drive cross-disciplinary collaboration' (p. 111). Although the development of IL was considered by the profession to be as Doskatsch (2003) identifies, 'educationally, professionally and politically desirable' (p. 114), more than a decade on, the literature clearly suggests the same challenges remain (Osborn 2017; Corrall \& Jolly, 2019). Bryant et al. (2020) lament that academic 
libraries can still be 'burdened by their historical role as a physical repository of print collections' (p. 12). The authors stress that to be considered a key figure in the university's educational landscape, the library 'in turn must communicate clearly to campus partners its full value proposition and expertise, making clear that this value and expertise extends to a broad range of services beyond books' (Bryant et al., 2020, p. 12). It is clear that libraries want to offer a greater contribution to learning and teaching in a rapidly changing global higher education sector, yet as Corrall and Jolly (2019) have emphasised, 'the role of librarians as teachers continues to be contested, questioned and resisted' (p. 114).

Literature in the field of library studies clearly espouses the benefits of embedding students' research skill development within disciplinary content (Bundy, 2004; Olivares, 2010; Torres \& Jansen, 2016). It is recognised that this is the most effective way to connect the library's skill development programmes with campus life and institutional educational priorities (Dewey, 2005). The challenge for library educators and discipline academics is how to incorporate and make library skill development programmes a relevant, embedded and coherent part of the student learning experience, and one which considers evolving pedagogy, teaching practice and curriculum design.

Although librarians have endeavoured to respond to the call to 'engineer the metamorphosis from librarian to educator and learning facilitator' with the profession's first edition of the ANZIL Standards in hand (Peacock, 2001, p. 27). Gaining a foothold in the curriculum was not without its challenges. Bundy (2004) identified that what was lacking in the first edition of the ANZIIL Standards was a way for librarians to guide and foster the development of IL skills within disciplinary content. The 2004 edition of ANZIL intended to rectify this, however, library and information studies literature still evidences a continuing struggle to meaningfully connect library IL programmes to skill agendas at the institutional level. Although there would be a number of contributing factors impeding the ability to activate the ANZIL Standards more broadly in disciplinary curricula, one reason could be that ANZIL describes 'what' information literacy skills are, not ' $h o w$ ' to activate and scaffold them coherently within learning content. Moselen and Wang (2014) also note that 'very little of [the literature] has discussed how to prepare librarians to become active contributors to curricular design in higher education' (p. 117). Related to this observation, ANZIL uses the language of librarianship rather than the language of educators which may also be a reason why the Standards have had limited reach beyond library audiences.

\subsection{Re-envisioning the Library's Educative Potential}

To recalibrate how Monash University Library contributes to students' skill development, learning skills advisers were integrated into the library's organisational structure to work collaboratively alongside teaching librarians (Smith, 2011). This new structure enabled the library to assume responsibility for a broad spectrum of skills, challenging historical assumptions of the library's role in the University (Smith, 
2011). The success of the initiative demonstrates industry leadership and a model that leverages a way forward for libraries to expand their skill repertoire and engage more directly, purposefully and impactfully in the curriculum.

It soon became apparent, however, that this new partnership required an enabling tool to underpin and guide a reconceptualised library teaching practice. This tool needed to clarify what skills and expertise the librarian and learning skills adviser brought to this partnership, where their areas of knowledge and educational expertise lay, where they differed and where they overlapped. The tool also needed to not only harness the expertise of these educators, but guide and inform a new collaborative teaching structure.

To this end, MUL adopted and implemented the Research Skill Development (RSD) framework (Willison \& O'Regan 2006/2018) in 2009, rather than the ANZIL Standards themselves. The RSD framework is a conceptual pedagogical model for guiding students' research skill development in the curriculum. Such a tool made sense in a context where MUL was reconceptualising and expanding its IL skill repertoire to include both research and learning skills. Therefore, the RSD signalled a way to guide how library research skill programmes could be embedded into disciplinary curricula so that the skills students required for researching were not artificially divorced from content knowledge. As such, the RSD heralded a promise to also underpin library-faculty teaching partnerships and in doing so, enable the library to achieve its strategic educational goal of embedding skills explicitly into the curriculum. In alignment with the RSD framework, the library adopted the terms 'research skills' and 'research and learning skills' as this nomenclature was also considered more appropriate to an academic learning environment (Smith, 2011). 'Research and learning skills' also communicate a holistic articulation of the skill expertise of librarians and learning skills advisers. With the RSD in hand, librarians and learning skills advisers had a way to overcome the challenge of how educators from across the university conceive research skills across disciplines. Since adopting the RSD framework in 2009, MUL has successfully enhanced collaborative libraryfaculty teaching partnerships for the explicit development of students' research skills as considered aspects of learning in a range of disciplines (Torres \& Jansen, 2016).

The RSD framework is the first of a suite of skill development frameworks that have been created over the years that have been inspired by the sophisticated simplicity, effectiveness and adaptability of the RSD. The RSD framework together with sibling frameworks explicating work and digital skills respectfully are referred to collectively as the Models of Engaged Learning and Teaching (Willison, 2017). The sections that follow will unpack the guiding parameters of the MELT. 


\subsubsection{Opening a New Conversation for Students' Skill Development}

Discovering the RSD was quite serendipitous, and occurred through a library conference presentation by the creator of the MELT, Dr John Willison in 2008. The RSD framework immediately resonated for a library context, primarily because of its foundational underpinning with the ANZIL Standards (ANZIIL, 2004). The ANZIL Standards have informed the Facets of Research in the RSD framework. By overlaying the ANZIL Standards with Bloom's Taxonomy (Bloom et al., 1956), the RSD has essentially breathed life into the ANZIL Standards. Furthermore, the RSD framework has provided librarians with an important missing link - that is, by guiding educators as to what information literacy skills are and how they can be activated in library skill development programmes. This is significant because as early as 2001, the international library sector was lamenting that teachers and students alike did not have a 'roadmap' or a 'blueprint' to unpack the concept of IL, adding to the confusion was an understanding of the range of skills involved and as such, hampering their traction in the curriculum (Koch, 2001).

The RSD Handbook disseminated at this library conference included the names of two academics from Business and Economics at Monash University who were applying the RSD framework to their teaching. On contacting the academics with an offer to meet, there was great interest from both parties to learn about each other's interest and application of the RSD framework. The academics were keen to hear why the library was considering the RSD, and we, at the library, were keen to learn how the RSD framework was being applied in a disciplinary context. At our meeting, we placed the RSD framework as a conversation piece between us on the table. The conversation the RSD ignited was stimulating, insightful, surprising, extremely productive and positive. The RSD provided the means to have a conversation using a mutually understood language, helping us as library staff to discuss research skill development using the language of educators rather than through library-centric terminology. Centring the conversation around the RSD framework enabled us to discover and describe our common educative goals and our shared trajectoryenabling students to engage with discipline content and succeed in their studies. This meeting over the RSD was pivotal and sparked a partnership which has evolved and continued over the years, the RSD framework providing the foundational structure for the collaboration. This teaching partnership has offered opportunities to pilot and co-create teaching and learning initiatives informed by the RSD, co-facilitate RSD workshops across the university, present at international education conferences and over the years, contribute to funded research on the RSD framework (Willison, 2012; Willison et al., 2010). As the collaboration has progressed and continued over time, different library staff have been involved and have contributed to the collaboration which remains strong today (see Chap. 14 by Gleeson, Junor and Mayson). 


\subsection{The Theoretical Underpinnings of the MELT}

The MELT frameworks are pedagogical conceptual models that individually articulate a range of academic skills and facilitate how Graduate Attributes can be animated in the curriculum. The MELT frameworks consist of three theoretical parameters. The vertical axis describes the 'Skill Facets' presented as verb couplets and informed by Bloom's Taxonomy of Learning (Bloom et al., 1956). The horizontal axis, 'Scope for Student Autonomy', depicts a learning continuum informed by Vygotsky's Zone of Proximal Development (1978), Biggs and Collis' SOLO Taxonomy (1982) and the work of Boud (1988) on learner autonomy. Lastly, the adjectives in italics running alongside each skill couplet or 'facet' capture the affective domain (Krathwohl et al., 1964) — that is, the dominant attitude or disposition of the learner required to develop that skill. What differentiates the MELT frameworks from other skill frameworks is that they are conceptual models that when contextualised, provide a way to distil and scaffold the skills required for complex thinking. This offers library-faculty teaching partnerships a way to address the challenge of making implied skills visible in the curriculum. Therefore, it is through contextualisation and application that the MELT reveal their student-centredness, adaptability, sophistication and richness. Empirical studies applying the MELT in a range of disciplines have shown their potential to guide educators in their teaching as much as guide students in their learning (Torres, 2018; Willison, 2018).

\subsection{Unpacking the Parameters of the MELT}

\subsubsection{The Vertical Axis: Skill Facets and the Concept of the Affective Domain}

The vertical axis of each of the MELT frameworks individually describe the skill development associated with that framework, i.e. RSD framework (research; see Fig. 2.1), WSD framework (work; see Fig. 2.2) and DSD framework (digital skills; see Fig. 2.3). In each framework, the reader will notice that the skills are depicted as verb couplets and are referred to as 'facets' (as in the 'facets' of a diamond). This is to give the impression of 'skill clusters' that relate and overlap with one another and importantly, need to be developed in tandem. Each facet is accompanied by a descriptor informed by Bloom's cognitive domain (Bloom et al., 1956). The descriptor is meant to encapsulate the essence of the Skill Facet by describing what the learner is doing at that point of their research (RSD framework), workplace activity/practice (WSD framework) or in using digital technology (DSD framework). A guiding question is also included, which 'unpacks' the facet by personalising and expressing the skill through the 'learner voice'. 


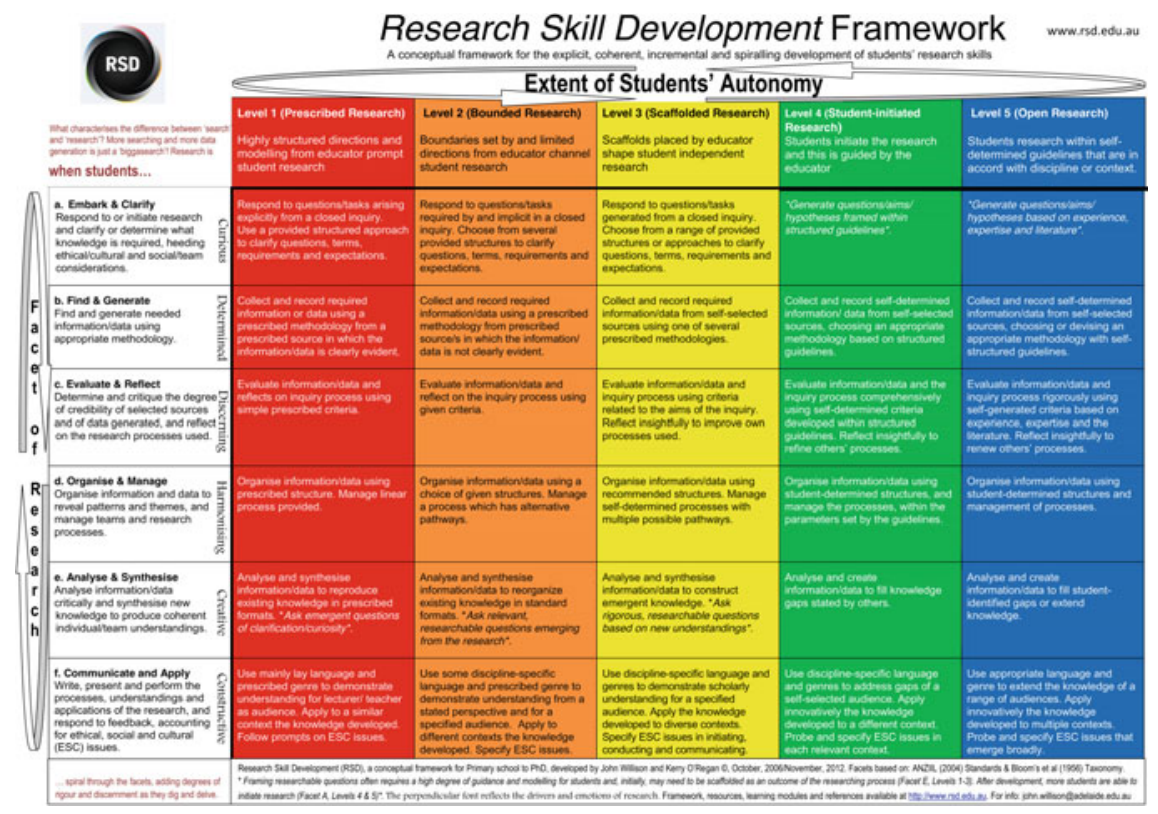

Fig. 2.1 The Research Skill Development (RSD) framework. Willison and O'Regan (2006/2018). Reproduced with permission

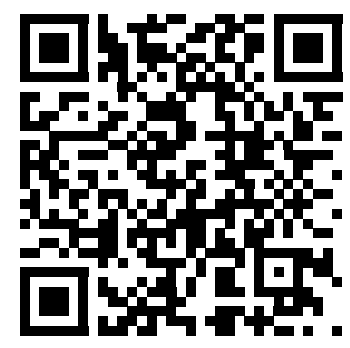

\subsubsection{The Concept of the Affective Domain}

The affective domain, defined as values, motivators and drivers (Krathwohl et al., 1964) or as dispositions and attitudes, accompanies the Skill Facets (cognitive domain) of each of the MELT frameworks. The affective domain is represented by an adjective with each Skill Facet. These adjectives describe the positive emotions, attitudes and dispositions most indicative of each facet (i.e. the dominant disposition that describes that skill). The affective domain points to the importance of students recognising and developing attitudes and dispositions for learning together with skills. 


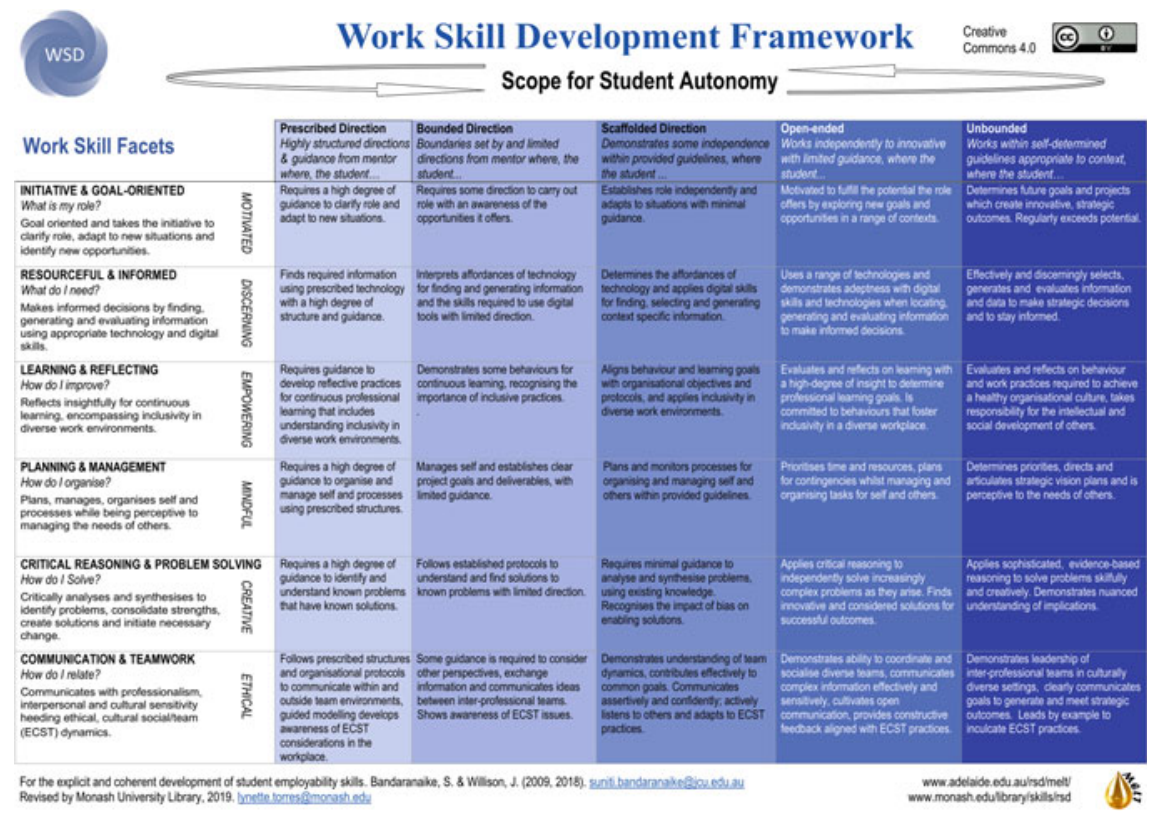

Fig. 2.2 The Work Skill Development (WSD) framework. Bandaranaike and Willison (2009/2018). Revised by Monash University Library, 2019. Reproduced with permission

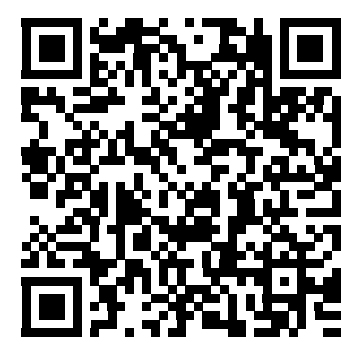

The inclusion of the affective domain, and associating it with the cognitive skills described in the facets, shifts the focus from a teacher-centred viewpoint to a studentcentred one. The role of the affective domain in specific association with the skills and processes of researching has been explored by Kuhlthau (2004). Kuhlthau insightfully draws connections between students' affective dispositions ignited by the uncertainty of charting unfamiliar territory during the process of seeking and using information, and refers to this experience as the uncertainty principle. Kuhlthau (2004) states that.

Uncertainty is a cognitive state which commonly causes affective symptoms of anxiety and lack of confidence. Uncertainty and anxiety can be expected... confusion and frustration are associated with vague, unclear thoughts about a topic or question (p. 341). 


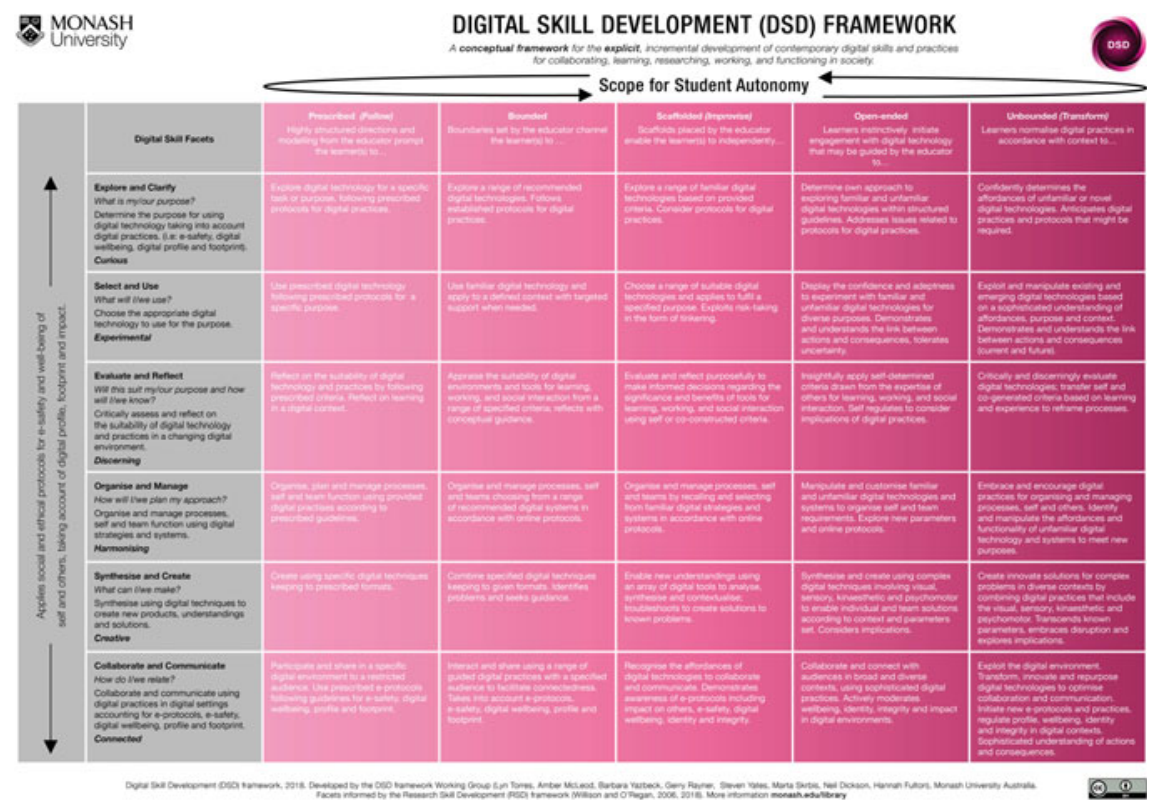

Fig. 2.3 The Digital Skill Development (DSD) framework. Torres et al. (2018). Reproduced with permission

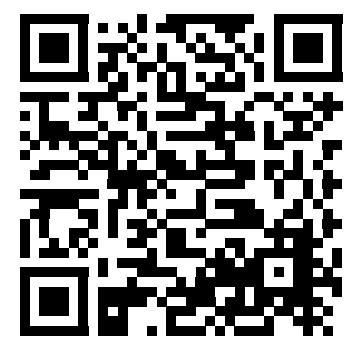

Although the MELT frameworks focus solely on adjectives that describe positive dispositions, by acknowledging the affective domain, they draw the educator's attention to the importance of the range of dispositions and attitudes that are part of an individual's experience of learning. In a library context where the primary orientation of library programmes is to teach students skills for researching, it is important to acknowledge that feelings of uncertainty, anxiousness and frustration also accompany the information seeking process. The MELT frameworks have provided a way to conceptualise how the theoretical principle of uncertainty marries with a constructivist approach to learning. As library educators, being aware of the theoretical principles related to the affective domain in our teaching practice makes us more sensitive to what we need to consider when designing skill development classes. 


\subsubsection{The Horizontal Axis: Scope for Student Autonomy}

The MELT share a horizontal axis, the 'Scope for Student Autonomy', where the degree of learner independence is described in incremental and progressive stages across a learning continuum. Autonomy is widely acknowledged as an important aim in education as increasing self-reliance enables students to gain awareness of themselves as learners and in doing so, take control and responsibility for their learning (Boud, 1988; Bruce, 1994; Butler, 1999; Fazey \& Fazey, 2001). As Willison (2018) points out, the facets 'reveal "what" skills are and the levels of autonomy show "how" to facilitate the facets, by providing a sense of the level of structure and guidance required by students' (p. 4). Student autonomy is described through scaffolded increments across the MELT learning continuum. Willison et al. (2017) note that descriptors guide the educator's intervention by the question: 'How much guidance and space do these students need?' The intention of the autonomy continuum is to build student independence or self-reliance with each skill over time. Autonomy ranges from Prescribed guidance where close educator or supervisor guidance is required through to Unbounded autonomy where the learner is able to perform activities independently and has the ability to extend the skills as described to new contexts.

Autonomy is a sophisticated concept which acknowledges that skills develop and progress at different rates (Willison et al., 2017). Unlike competency frameworks such as the Australian and New Zealand Information Literacy Standards (ANZIIL, 2004) which suggests learning is unidirectional and can be benchmarked (i.e. whether a student can demonstrate the ability to do something to a certain level or not), the focus of the MELT frameworks is on learning. The Association of College and Research Libraries Framework for Information Literacy for Higher Education (ACRL, 2015) presents a renewed vision by introducing key threshold concepts for information literacy 'to encourage a deeper understanding of what knowledge practices and dispositions an information literate student should develop' (ACRL, 2015, p. 10). However, the ACRL Framework still lacks a developmental view of learning. A learning continuum framed by learner autonomy as captured by the MELT framework acknowledges that students may be positioned at various points on the autonomy continuum in relation to different skills and tasks at any one time. Autonomy depends on context, purpose and learner characteristics.

The scope of autonomy is also fluid in that a single task may shift through varying levels of autonomy as learners build competence and self-regulate their learning (Willison et al., 2017). In this way, the MELT recognises that students may demonstrate varying levels of autonomy for the different skills and that students may oscillate between these skills whilst engaged in a task. A learning continuum informed by learner autonomy recognises that students may at times move backwards when faced with less familiar activities, tasks or concepts that are new to the learner and therefore more conceptually demanding. As explained by Willison et al. (2017), 'this does not mean going backwards educationally, but rather provides insight into what 
happens in more conceptually demanding contexts, when students move into unfamiliar territory or when more rigour is required' (p. 3). As noted earlier, this aspect of autonomy is also mirrored in earlier work on information seeking behaviour by Kuhlthau (2004), and is referred to as moving from 'uncertainty to understanding' (p. 340). It is likely, therefore, that a learner will move along the continuum with every unfamiliar task.

The MELT makes it possible for an educator to reflect on how much guidance might be required for a particular task or learning activity and 'pitch' or scaffold the activity accordingly. In considering how much space needs to be created by the educator for autonomous learning to take place, moderate autonomy where room is provided for the individual to manoeuvre between dependence and independence, has been considered preferable to having full autonomy (Wielenga-Meijer et al., 2011; Zoghi \& Dehghan, 2012). With this in mind, Willison et al. (2017) suggest that "teachers should facilitate the level of guidance which produces the "sweet spot" for optimum learning and thinking', as such the authors conclude that, 'education generally, and the development of research skills in particular, would progress most successfully for a whole cohort when in this middling educational "Goldilocks zone", (p. 430).

Therefore, from a teaching perspective (Willison et al., 2017) describe autonomy as a 'tug of war', where the degree of autonomy shifts according to.

...personal elements and the demands of disciplines, work or required competence. Autonomy is more a relationship between people and their learning environment and less a measurable entity or characteristic that increases unidirectionally: It is more about appropriate levels of conceptual space as each context warrants (p. 11).

Autonomy can therefore be considered as the extent of scaffolding and conceptual space required for optimal learning to take place. Willison (2020) notes that when educators facilitate learning, they 'enhance student metacognition' and students' ability to 'regulate their own learning' (p. 131). An optimal learning environment also acknowledges the interplay and inter-relatedness of affective skills and dispositions for supporting the student to over time, take control of their learning by gradually increasing their self-reliance (Bandura, 1997). As Bandaranaike and Willison (2017) put it, 'engaging in learner autonomy requires a wide selection of personal and interpersonal skills, and a range of cognitive, metacognitive, affective and social skills' (p. 6).

As autonomy descriptors provide educators with a continuum for designing incremental and scaffolded learning activities that make the skills embedded in the activities explicit, the MELT can guide educators in overcoming the predicament of how to chart the developmental progression of student skills. This means the MELT offer a way to teach and assess skills coherently in the curriculum (Bandaranaike, 2018; McLeod \& Torres, 2020; Peirce et al., 2009; Pretorius et al., 2013; Torres \& Jansen, 2016). This is significant for library skill development programmes, as a scaffolded approach to developing students' research skills in the context of higher education is often overlooked and even neglected by library skill development programmes. 
The following section highlights the distinctive elements of each of the MELT frameworks, the Research Skill Development (RSD) framework, the Work Skill Development (WSD) framework and the Digital Skill Development (DSD) framework, that are explored in the practice-based examples in the book chapters that follow.

\subsection{The Research Skill Development (RSD) Framework}

The RSD framework is designed to explicitly guide the cyclic development of students' research skills (Willison \& O'Regan, 2007). While the RSD framework was not created specifically with library programmes in mind, it immediately resonated with MUL when the library sought a pedagogical framework to guide its teaching practice. The RSD connected well to a library context in that it is derived from the ANZIL Standards (ANZIIL, 2004). As such, the RSD framework indicated strong potential to guide teaching collaborations between librarians and learning skills advisers, and in doing so, bring together educators with complementary skills and knowledge for a new organisational teaching structure. Further validating the potential of the RSD framework to guide and underpin the library's teaching practice is Willison and O'Regan's (2007) acknowledgement that in creating the RSD framework, the ANZIL Standards appropriately capture a set of skills (see Table 2.1) that together make for effective and appropriate use of information, considered by the authors an essential part of the research process.

The RSD framework on the other hand, offers a reconceptualised interpretation of ANZIL by overlaying the six ANZIL Standards with Bloom's Taxonomy (Bloom et al., 1956). By explicating these six research skills across a learning continuum, Willison and O'Regan (2007/2018) effectively offer library educators the missing 'roadmap' or 'blueprint' to guide library-faculty partnerships and the way in which the library responds to student learning. Therefore, the significance of the RSD framework is in offering a reconceptualised interpretation of the ANZIL Standards, where information literacy skills are overlaid with and scaffolded progressively across a theoretically informed learning continuum.

While the Skill Facets in the RSD framework are represented sequentially to capture the research process, they are not lockstep or linear. In fact, the RSD recognises that research is not only a recursive process, but a process that can also be messy as the researcher moves back and forth between Skill Facets. The facets make these complex phases of research visible, they suggest a logical pathway through this nuanced process that is both iterative and non-linear. In this sense, the facets are dynamic and adaptable; they share elements of each other allowing for context-sensitive application to research. It is when the facets are contextualised that research skills and the processes associated with research are revealed. Willison and Buisman-Pijlman (2016) emphasise this and also stress that the RSD facets are not: 
...generic skills, as this would imply a ready transferability, but rather they are overarching perspectives about the research processes that are common across disciplines. In use, these general descriptions are made real by academics who operationalise them as disciplinespecific and context-sensitive descriptors (p. 66).

The adoption of the RSD framework across the university has been led by MUL and has been applied in partnership with academic staff to a range of disciplinary contexts. This includes Law (Hughes et al., 2011), Nursing and Midwifery (Pretorius et al., 2013), Business and Economics (Taib \& Holden, 2013), Business Law (Kananatu, 2017), Creative Writing (Wong \& Yahya, 2017), Engineering (Karu et al., 2017), Biological Sciences (Torres, 2018). In this volume, the RSD framework is explored in Business Management (see Chap. 14 by Gleeson, Junor and Mayson), in Law (see Chap. 8 by Brabon, Tucker, Pulungan and Lang), in an interdisciplinary master's programme in Environment and Sustainability (see Chap. 5 by Castillo and Ho), in a Nursing master's unit (see Chap. 12 Turner, Young, Freeman \& Zahora) as well as Business and Economics at Monash University Malaysia (see Chap. 7 by Kananatu, Santra and Yahya) and in Art and Design (see Chap. 13 by Manuell).

\subsection{The Work Skill Development (WSD) Framework}

In recent decades, the focus in higher education has shifted to producing job-ready graduates with a broad range of skills and attributes which transfer well to workplace settings. The WSD framework is a pedagogical tool that facilitates the conceptualisation and explicit development of students' work skills. The WSD framework offers a way for educators to bridge the gap between university curricula and industry requirements. In this way, the WSD contributes to WIL (Work Integrated Learning) pedagogy by conceptualising and facilitating the explicit development of students' work skills, and informing and guiding student assessment in WIL as well as regular curriculum (Bandaranaike \& Willison, 2010).

The WSD framework provides a structure and learning trajectory that enables educators to scaffold the incremental development of work skills in either existing or new curriculum as well as WIL experiences. This suggests practical applications such as informing course design, framing learning tasks, activities and assessment design. Therefore, the WSD framework supports educators to plan and set learning goals, so that students can see how their work skills are progressing. As a self-reflective tool, the WSD helps students to identify their work skills, what skills might be required in a given role, how to monitor their skill development and a way to interpret how autonomously they might be expected to work in a given role in regard to certain skills.

The WSD framework consists of Work Skill Facets (see Table 2.1) that describe a range of higher order cognitive skills and processes required in a work context. Like the RSD, each Skill Facet is represented as a verb pair (i.e. Initiative and Goaloriented). The verb pair is intended to capture the complementary nature of these skills. While these capabilities may be mutually exclusive, they are more likely 
Table 2.1 Skill facets of the RSD (2018), WSD (2019) and DSD (2018) frameworks demonstrating the inter-relatedness of the MELT facets (cognitive skills, the affective domain and guiding questions pertaining to each facet)

\begin{tabular}{|c|c|c|}
\hline \multicolumn{3}{|l|}{ Skill facets } \\
\hline $\begin{array}{l}\text { Research Skill (RSD) } \\
\text { Development framework }\end{array}$ & $\begin{array}{l}\text { Work Skill (WSD) } \\
\text { Development framework }\end{array}$ & $\begin{array}{l}\text { Digital Skill (DSD) } \\
\text { Development framework }\end{array}$ \\
\hline $\begin{array}{l}\text { Embark and clarify What is our } \\
\text { purpose? Curious }\end{array}$ & $\begin{array}{l}\text { Initiative and } \\
\text { goal-oriented What is my } \\
\text { role?Motivated }\end{array}$ & $\begin{array}{l}\text { Explore and clarify What is } \\
\text { my/our purpose?Curious }\end{array}$ \\
\hline $\begin{array}{l}\text { Find and generate What do we } \\
\text { need?Determined }\end{array}$ & $\begin{array}{l}\text { Resourceful and } \\
\text { informedWhat do I } \\
\text { need?Discerning }\end{array}$ & $\begin{array}{l}\text { Select and useWhat will I/we } \\
\text { use?Experimental }\end{array}$ \\
\hline $\begin{array}{l}\text { Evaluate and reflect What do we } \\
\text { trust?Discerning }\end{array}$ & $\begin{array}{l}\text { Learning and reflecting How } \\
\text { do I improve?Empowering }\end{array}$ & $\begin{array}{l}\text { Evaluate and reflectHow will } \\
\text { I/we know?Discerning }\end{array}$ \\
\hline $\begin{array}{l}\text { Organise and manageHow do } \\
\text { we arrange?Harmonising }\end{array}$ & $\begin{array}{l}\text { Planning and } \\
\text { management How do I } \\
\text { organise?Mindful }\end{array}$ & $\begin{array}{l}\text { Organise and manage How will } \\
\text { I/we plan the } \\
\text { approach?Harmonising }\end{array}$ \\
\hline $\begin{array}{l}\text { Analyse and synthesise What } \\
\text { does it mean?Creative }\end{array}$ & $\begin{array}{l}\text { Critical reasoning and } \\
\text { problem solvingHow do I } \\
\text { solve? Creative }\end{array}$ & $\begin{array}{l}\text { Synthesise and createWhat can } \\
\text { I/we make? Creative }\end{array}$ \\
\hline $\begin{array}{l}\text { Communicate and applyHow } \\
\text { do we relate?Constructive }\end{array}$ & $\begin{array}{l}\text { Communication and } \\
\text { teamworkHow do I } \\
\text { relate?Ethical }\end{array}$ & $\begin{array}{l}\text { Collaborate and } \\
\text { communicateHow do I/we } \\
\text { relate?Connected }\end{array}$ \\
\hline
\end{tabular}

to be complementary and co-dependent. That is, they describe a cluster of skill categorisations best developed in tandem. Like the RSD framework, the Skill Facets of the WSD do not sit in isolation, they are multi-faceted in that they overlap and share elements of each other.

The value of the WSD for the library's teaching practice has been in describing how the skills students develop as part of their university education can also be articulated as skills valued by the workplace. The WSD was developed in response to a need to do the following: assess students' work readiness (Bandaranaike \& Gurtner, 2017; Bandaranaike, 2018) in a range of domains including emotional and cultural intelligence; provide feedback to students in internships; and guide reflective conversations on work skill development with students (Bandaranaike, 2018). It has been useful in conceptualising a self-reflective approach where students align their work skills with autonomy descriptors (Torres et al., 2014). As such, uptake of the WSD framework has been led by MUL and applied to framing learning tasks, activities and assessment design in disciplines such as Accounting and Finance, Business and Economics and Law (Torres et al., 2014). In this volume, we share how the WSD has been used to map competency standards for Occupational Therapy to facilitate the library's response to student learning (see Chap. 18 by Todd, Khoshsabk, Torres and Peart) and to guide and monitor a Library Internship Program for Korean Studies students (see Chap. 17 by Dewi, Kim and Jackson) highlighting how skills gained through study can transfer to the workplace (Table 2.2). 
Table 2.2 Student autonomy as described in the MELT (RSD, WSD and DSD frameworks), demonstrating how the autonomy descriptors for each of these frameworks relate to one another

\begin{tabular}{|c|c|c|c|c|c|}
\hline & \multicolumn{5}{|c|}{ Models of Engaged Learning and Teaching (MELT) } \\
\hline & \multicolumn{5}{|c|}{ Scope for student autonomy } \\
\hline & Prescribed & Bounded & Scaffolded & Open-ended & Unbounded \\
\hline $\begin{array}{l}\text { Research Skill } \\
\text { Development } \\
\text { (RSD) } \\
\text { framework }\end{array}$ & $\begin{array}{l}\text { Highly } \\
\text { structured } \\
\text { directions } \\
\text { and } \\
\text { modelling } \\
\text { from } \\
\text { educator } \\
\text { prompt } \\
\text { researching } \\
\text { in which ... }\end{array}$ & $\begin{array}{l}\text { Boundaries } \\
\text { set by and } \\
\text { limited } \\
\text { directions } \\
\text { from } \\
\text { educator } \\
\text { channel } \\
\text { researching } \\
\text { in which ... }\end{array}$ & $\begin{array}{l}\text { Scaffolds } \\
\text { placed by } \\
\text { educator } \\
\text { shape } \\
\text { independent } \\
\text { researching } \\
\text { which ... }\end{array}$ & $\begin{array}{l}\text { Student initiate } \\
\text { research and } \\
\text { this is guided } \\
\text { by the educator }\end{array}$ & $\begin{array}{l}\text { Students } \\
\text { determine } \\
\text { guidelines for } \\
\text { researching that } \\
\text { are in accord } \\
\text { with discipline } \\
\text { or context }\end{array}$ \\
\hline $\begin{array}{l}\text { Work Skill } \\
\text { Development } \\
\text { (WSD) } \\
\text { framework }\end{array}$ & $\begin{array}{l}\text { Highly } \\
\text { structured } \\
\text { directions } \\
\text { and } \\
\text { guidance } \\
\text { from } \\
\text { mentor } \\
\text { where the } \\
\text { student ... }\end{array}$ & $\begin{array}{l}\text { Boundaries } \\
\text { set by and } \\
\text { limited } \\
\text { directions } \\
\text { from } \\
\text { mentor } \\
\text { where, the } \\
\text { student ... }\end{array}$ & $\begin{array}{l}\text { Demonstrates } \\
\text { some } \\
\text { independence } \\
\text { within } \\
\text { provided } \\
\text { guidelines } \\
\text { where the } \\
\text { student ... }\end{array}$ & $\begin{array}{l}\text { Works } \\
\text { independently } \\
\text { to innovate with } \\
\text { limited } \\
\text { guidance where } \\
\text { the student ... }\end{array}$ & $\begin{array}{l}\text { Works within } \\
\text { self-determined } \\
\text { guidelines } \\
\text { appropriate to } \\
\text { context, where } \\
\text { the student ... }\end{array}$ \\
\hline $\begin{array}{l}\text { Digital Skill } \\
\text { Development } \\
\text { (DSD) } \\
\text { framework }\end{array}$ & $\begin{array}{l}\text { Highly } \\
\text { structured } \\
\text { directions } \\
\text { and } \\
\text { modelling } \\
\text { from the } \\
\text { educator } \\
\text { prompt the } \\
\text { learner(s) to } \\
\ldots\end{array}$ & $\begin{array}{l}\text { Boundaries } \\
\text { set by the } \\
\text { educator } \\
\text { channel the } \\
\text { learner(s) to } \\
\ldots\end{array}$ & $\begin{array}{l}\text { Scaffolds } \\
\text { placed by the } \\
\text { educator } \\
\text { enable the } \\
\text { learner(s) to } \\
\text { independently } \\
\text {.. }\end{array}$ & $\begin{array}{l}\text { Learners } \\
\text { instinctively } \\
\text { initiate } \\
\text { engagement } \\
\text { with digital } \\
\text { technology that } \\
\text { may be guided } \\
\text { by the educator } \\
\text { to ... }\end{array}$ & $\begin{array}{l}\text { Learners } \\
\text { normalise and } \\
\text { digital practices } \\
\text { in accordance } \\
\text { with context to } \\
\text {.. }\end{array}$ \\
\hline
\end{tabular}

\subsection{The Digital Skill Development (DSD) Framework}

A world transformed by technology has brought new considerations for what it means for students to be digitally literate and what educators might be required to do to enable such skills in the curriculum (Goodfellow, 2011; McMahon, 2014). However, defining the dimensions inherent in digital literacy is a complex undertaking as digital literacy incorporates a sophisticated and broad range of skills. Perceiving digital literacy as pertaining solely to a set of technical skills over-simplifies their scope. A more expansive view of digital literacy incorporates a range of overlapping cognitive and interpersonal skills, attitudes, dispositions and practices in conjunction with technical skills (Feerrar, 2019). However, the complex nature of this skill set can challenge educators in explicitly describing and developing digital skills 
within programmes of study (McMahon, 2014). This would suggest that describing digital skills and attributes calls for a taxonomy of terms to enable, evidence and guide learning practices (Stordy, 2015). However, Spante et al. (2018) in surveying the literature, note that defining the diversity of concepts related to digital literacy remains problematic. Within the context of higher education, establishing a common understanding of digital literacy remains evident, as policy and institutional documents would benefit from reflecting a more expansive view of this skill range, as well as greater consistency in defining what digital literacy encompasses (Feerrar, 2019; Spante et al., 2018).

A library-led initiative in partnership with discipline academics was established to create a suitable pedagogical tool to articulate and support the progressive development of digital skills for a variety of learning contexts. Libraries have a long history of being involved with IL and consider digital literacy as an expansion of this skill set. As such, digital skill frameworks have been created by academic libraries, to help demonstrate how IL skills connect to digital literacy (Feerrar, 2019). A number of digital skill frameworks created for educational contexts were examined and reviewed as part of the working group's initial project scoping. These frameworks were comprehensive and drew on a range of knowledge domains including cognitive and metacognitive, affective, psychomotor, social, personal and technical, however, although the frameworks covered an extensive range of digital skills, we concluded they carried certain shortcomings.

The overall focus was often information-centric, meaning, they sometimes focussed on finding, using and evaluating information in online settings. This risks a limited interpretation of the digital practices that are required to function effectively in contemporary digital settings, be they learning, social or workplace settings. In addition, most frameworks lacked an important developmental perspective to guide skill progression. Consequently, this limited the potential of these frameworks as pedagogical tools for explicitly guiding digital skill development within curricula.

In response to this identified gap, the DSD framework was developed to provide guidance to educators in enabling students' digital skills within a range of learning contexts. In order to address the complexity of what it means for students to be digitally literate, the DSD working group developed the following working definition of digital skills:

The contemporary digital skills and attributes required to engage with technologies for learning, researching, working, and functioning in society in the digital age. This involves consuming, collaborating and creating with digital tools, and takes into account digital identity, digital wellbeing and e-Safety (Digital Skill Development framework 2018).

The DSD framework is informed by the same pedagogical underpinnings and parameters as the earlier MELT, and therefore, offers a flexible, adaptable and nonprescriptive conceptual model to guide educators in enabling students' digital skills. The term 'digital skills' rather than 'literacy' was chosen because it aligns with the parameters of the MELT, ensuring consistency with these models. The DSD framework is being applied to provide pedagogical guidance in recognising, identifying, enabling and expanding the repertoire of contemporary digital skills required by 
students to meet the demands of learning, social life and employment in a digital age (McLeod \& Torres, 2020; Torres et al., 2018). A chapter exploring the DSD in a workshop for students undertaking an Education Pathways unit (see Chap. 15 by Pilz, McLeod and Yazbeck) is presented in this book.

\subsection{Summarising the Characteristics of the MELT}

The MELT actively facilitates student learning in ways that enable students' skills to grow in sophistication and rigour (Willison, 2018). The characteristics of the MELT make the developmental side of learning visible through the three guiding parameters of the frameworks: the cognitive domain (Skill Facets), the Scope for Student Autonomy and the affective domain. When engaging with the MELT, it is often useful to remember the frameworks have the following characteristics:

- Conceptual models

- Pedagogical tools

- Learning continuums

- Tools to inform assessment and curriculum design

- Flexible, adaptable, dependent on context

- Applicable to a range of curricula and learning contexts

- Offering a common language for research skill development amongst educators

- In synergy with educational strategies

On the other hand, the MELT have shown not to be.

- Assessment rubrics

- Prescriptive and inflexible

- A set of rules

- Lockstep

A benefit of the MELT is that each framework shares the same guiding parameters and theoretical principles. Therefore, familiarity with one of the MELT enables understanding of another of the MELT frameworks. This has been invaluable for establishing shared knowledge of the MELT across library teaching teams and for building library staff confidence in selecting and applying the most appropriate MELT framework for a given context.

The significance of the MELT for library educational strategies and goals has been in the way these pedagogical tools have opened and guided a new discourse for students' skill development, enabling the library to transform, extend and deepen its educational practice in a highly sophisticated way. The MELT has offered a way to overcome the dilemma faced by library staff, in how to identify, articulate and chart the movement of students' research skill development, as well as how to facilitate that movement. By providing a common language through which educators from across the university can underpin collaborative approaches to teaching, learning, curriculum and assessment design. Of significance, the MELT has catalysed a deeper 
understanding of the professional, pedagogic and discipline-based perspectives of our practice, and what we share in common with educators across the university.

\section{References}

American Library Association (ALA). (2000). ACRL standards: Information literacy competency standards for higher education. College \& Research Libraries News, 61(3), 207-215. https://doi. org/10.5860/crln.61.3.207

Australian \& New Zealand Institute of Information Literacy (ANZIIL). (2004). In A. Bundy (Ed.), Australian and New Zealand information literacy framework: Principles, standards and practice (2nd ed.). Australian and New Zealand Institute for Information Literacy. Retrieved from https:// www.utas.edu.au/_data/assets/pdf_file/0003/79068/anz-info-lit-policy.pdf.

Association of College and Research Libraries. (2015). Framework for information literacy for higher education. Retrieved from http://www.ala.org/acrl/Standards/ilframework.

Bandaranaike, S. (2018). From research skill development to work skill development. Journal of University Teaching \& Learning Practice, 15(4), 1-18.

Bandaranaike S., \& Gurtner, Y. (2017, June 5-8). Integrating cross cultural sensitivity in the workplace: Developing globally proficient professionals. Paper presented at 20th World Conference on Cooperative and Work Integrated Learning (WACE), Chiang Mai, Thailand. Retrieved from https://www.researchgate.net/publication/304571323_Integrating_Cross_ Cultural_Sensitivity_in_the_Workplace_Developing_Globally_Proficient_Professionals.

Bandaranaike, S., \& Willison, J. (2009/2018). Revised by Monash University Library, 2019. Work skill development framework. Retrieved from https://www.monash.edu/_data/assets/pdf_file/ 0005/1719401/WorkSkillsDevt-2019.pdf.

Bandaranaike, S., \& Willison, J. (2010, September 27-October 1). Work skill development framework: An innovative assessment for work integrated learning. Paper presented at ACEN 2010: Australian Collaborative Education Network National Conference, Perth, WA, Australia.

Bandaranaike, S., \& Willison, J. (2017, June 5-8). Building learner autonomy into work-integrated learning: Challenges for the 21st century. Paper presented at 20th World Conference on Cooperative and Work Integrated Learning (WACE), Chiang Mai, Thailand. Retrieved from https://dig ital.library.adelaide.edu.au/dspace/bitstream/2440/97926/3/hdl_97926.pdf.

Bandura, A. (1997). Self-efficacy: The exercise of control. W. H. Freeman and Company.

Barnett, R. (2000). Realizing the university: In an age of supercomplexity. Society for Research in Higher Education and the Open University Press.

Barnett, S. M., \& Ceci, S. J. (2002). When and where do we apply what we learn? A taxonomy for far transfer. Psychological Bulletin, 12(4), 612-637. https://doi.org/10.1037/0033-2909.128. 4.612

Barrie, S. C. (2004). A research-based approach to generic graduate attributes policy. Higher Education Research \& Development, 23(3), 261-275. https://doi.org/10.1080/072943604200023 5391

Biggs, J. B., \& Collis, K. F. (1982). Evaluating the quality of learning: The SOLO taxonomy. Academic Press.

Bloom, B., Engelhardt, M.D., Furst, E.J., Hill, W.H., \& Krathwohl, D.R. (1956). Taxonomy of educational objectives. David McKay.

Boud, D. (1988). Developing student autonomy in learning (2nd ed.). Kogan Page.

Boyer Commission on Educating Undergraduates in the Research University. (1998). Reinventing undergraduate education: A blueprint for America's research universities. Stoney Brook. Retrieved September 29, 2005, from https://files.eric.ed.gov/fulltext/ED424840.pdf. 
Brew, A. (2006). Learning to develop the relationship between research and teaching at an institutional level. New Directions for Teaching \& Learning, 2006(107), 11-22. https://doi.org/10. $1002 / \mathrm{tl} .241$

Brew, A. (2012). Teaching and research: New relationships and their implications for inquiry-based teaching and learning in higher education. Higher Education Research \& Development, 31(1), 101-114. https://doi.org/10.1080/07294360.2012.642844

Bruce, C. (1994). Portrait of an information-literate person. HERDSA News, 16(3), 9-11.

Bryant, R., Dortmund, A., \& Lavoie, B. (2020). Social interoperability in research support: Crosscampus partnerships and the university research enterprise. OCLC Research. https://doi.org/10. 25333/wyrd-n586.

Bundy, A. (2004). Australian and New Zealand information literacy framework: Principles, standards and practice. Australian and New Zealand Institute for Information Literacy. Retrieved from https://www.utas.edu.au/_data/assets/pdf_file/0003/79068/anz-info-lit-policy.pdf.

Butler, S. (1999). Catalysing student autonomy through action research in a problem centred learning environment. Research in Science Education, 29(1), 127-140. https://doi.org/10.1007/BF0246 1184

Council of Australian University Librarians. (2001). Information literacy standards. CAUL.

Corrall, S., \& Jolly, L. (2019). Innovations in learning and teaching in academic libraries: Alignment, collaboration, and the social turn. New Review of Academic Librarianship, 25(2-4), 113-128. https://doi.org/10.1080/13614533.2019.1697099

Dewey, B. I. (2005). The embedded librarian: Strategic campus collaborations. Resource Sharing \& Information Networks, 17(1-2), 5-17. https://doi.org/10.1300/J121v17n01_02

Doskatsch, I. (2002). Australian and New Zealand Institute for Information Literacy (ANZIIL): New body to champion information literacy. Australian Academic \& Research Libraries, 33(2), 113-116. https://doi.org/10.1080/00048623.2002.10755187

Doskatsch, I. (2003). Perceptions and perplexities of the faculty-librarian partnership: An Australian perspective. Reference Services Review, 31(2), 111-121. https://doi.org/10.1108/009073203104 76585

Fazey, D. M. A., \& Fazey, J. A. (2001). The potential for autonomy in learning: Perceptions of competence, motivation and locus of control in first-year undergraduate students. Studies in Higher Education, 26(3), 345-361. https://doi.org/10.1080/03075070120076309

Feerrar, J. (2019). Development of a framework for digital literacy. Reference Services Review, 47(2), 91-105. https://doi.org/10.1108/RSR-01-2019-0002

Head, A., Van Hoeck, M., Eschler, J., \& Fullerton, S. (2013). What information competencies matter in today's workplace? Library and Information Research, 37(114), 74-104.

Healey, M., \& Jenkins, A. (2009). Developing undergraduate research and inquiry. The Higher Education Academy. Retrieved from https://s3.eu-west-2.amazonaws.com/assets.creode.advanc ehe-document-manager/documents/hea/private/developingundergraduate_final_1568036694. pdf.

Hill, J., Walkington, H., \& France, D. (2016). Graduate attributes: Implications for higher education practice and policy: Introduction. Journal of Geography in Higher Education, 40(2), 155-163. https://doi.org/10.1080/03098265.2016.1154932

Hughes, P., Tucker, K., \& Knaggs, C. (2011). Sitting on the same bench: Complementing law learning outcomes. Journal of Academic Language \& Learning, 5(2), A50-A59. Retrieved from https://journal.aall.org.au/index.php/jall/article/view/150/109.

Goodfellow, R. (2011). Literacy, literacies and the digital in higher education. Teaching in Higher Education, 16(1), 131-144. https://doi.org/10.1080/13562517.2011.544125

Kananatu, T. (2017, December 11-13). Using the research skill development framework to construct marking rubrics for law assessments. Paper presented at I-MELT (Models of Engaged Learning and Teaching) Conference, Adelaide, Australia. Retrieved from https://www.adelaide.edu.au/ melt/ua/media/309/kananatuimelt2017paper.pdf. 
Karu, P., Tran Minh, H., \& Sta Maria, B. (2017, December 11-13) Using the optimising problemsolving pentagon as a basis for research skills in final year engineering. Paper presented at International Conference on Models of Engaged Learning and Teaching (I-MELT), Adelaide, Australia. Retrieved from https://www.adelaide.edu.au/melt/ua/media/408/purushimelt2017paper-1.pdf.

Koch, M. (2001). Information literacy: Where do we go from here? Technos: Quarterly For Education and Technology, 10(1), 20-26. Retrieved from http://www.technos.net/tg_10/1koch. htm.

Krathwohl, D. R., Bloom, B. S., \& Masia, B. B. (1964). Taxonomy of educational objectives [handbook 2: Affective domain]. Longman.

Kuhlthau, C.C. (2004). Seeking meaning: A process approach to library and information services. Libraries Unlimited.

McLeod, A., \& Torres, L. (2020, April 6-9) Enhancing first year university students' digital skills with the Digital Skill Development (DSD) framework. Paper presented at SITE Online Conference (Society for Information Technology and Teacher Education), New Orleans, LA.

McMahon, M. (2014). Ensuring the development of digital literacy in higher education curricula. In B. Hegarty, J. McDonald, \& S.-K. Loke (Eds.), Rhetoric and reality: Critical perspectives on educational technology.Proceedings ascilite Dunedin 2014 (pp. 524-528). Retrieved from http:// ascilite.org/conferences/dunedin2014/files/concisepapers/157-McMahon.pdf.

Moselen, C., \& Wang, L. (2014). Integrating information literacy into academic curricula: A professional development programme for librarians at the University of Auckland. The Journal of Academic Librarianship, 40(2), 116-123. https://doi.org/10.1016/j.acalib.2014.02.002

Oliver, B. (2013). Graduate attributes as a focus for institution-wide curriculum renewal: Innovations and challenges. Higher Education Research \& Development, 32(3), 450-463.

Olivares, O. (2010). The sufficiently embedded librarian: Defining and establishing productive librarian-faculty partnerships in Academic Libraries. Public Services Quarterly, 6(2-3), 140-149. https://doi.org/10.1080/15228959.2010.497468

Osborn, J. (2017). Librarians as teachers: Forming a learning and teaching community of practice. Journal of the Australian Library and Information Association, 66(2), 162-169. https://doi.org/ 10.1080/24750158.2017.1328633

Peacock, J. (2001). Teaching skills for teaching librarians: Postcards from the edge of the educational paradigm. Australian Academic \& Research Libraries, 32(1), 26-42. https://doi.org/10.1080/000 48623.2001.10755141

Peirce, E., Ricci, M., Lee, I., \& Willison, J. (2009, 30 September-2 October). First-year Human Biology students in the ivory tower. Paper Presented at National UniServe Science Annual Conference, University of Sydney, Sydney, Australia. Retrieved from https://www.adelaide.edu.au/melt/ ua/media/753/pdf-ivory.pdf.

Pretorius, L., Bailey, C., \& Miles, M. (2013). Constructive alignment and the research skills development framework: Using theory to practically align graduate attributes, learning experiences, and assessment tasks in undergraduate midwifery. International Journal of Teaching and Learning in Higher Education, 25(3), 378-387.

Smith, L. (2011). Monash University Library and learning: A new paradigm for a new age. Australian Academic \& Research Libraries, 42(3), 246-264. https://doi.org/10.1080/00048623.2011.107 22235

Spante, M., Hashemi, S.S., Lundin, M., \& Algers, A. (2018). Digital competence and digital literacy in higher education research: Systematic review of concept use. Cogent Education, 5(1). https:// doi.org/10.1080/2331186X.2018.1519143

Stordy, P. (2015). Taxonomy of literacies. Journal of Documentation, 71(3), 456-476. https://doi. org/10.1108/JD-10-2013-0128

Taib, A., \& Holden, J. (2013). 'Third generation' conversations-A partnership approach to embedding research and learning skills development in the first year. A practice report. The International Journal of the First Year in Higher Education, 4(2), 131-136. https://doi.org/10.5204/intjfyhe. v4i2.178. 
Torres, L. (2018). Research skills in the first year biology practical—Are they there? Journal of University Teaching and Learning Practice, 15(4). Retrieved from https://ro.uow.edu.au/jutlp/ vol15/iss $4 / 3$.

Torres, L., Bandaranaike, S., \& Yates, S. (2014, June 2-4). 'What skills do I have? What skills will I need?'-Building an employability skills profile through an online reflective learning program. Paper presented at 10th International Symposium on Cooperative and Work-Integrated Education, University West, Trollhattan, Sweden. Retrieved from https://researchonline.jcu.edu.au/38450/.

Torres, L., \& Jansen, S. (2016). Working from the same page: Collaboratively developing students' research skills across the university. Council for Undergraduate Research (CUR) Quarterly, 37(1), 26-33. https://doi.org/10.18833/curq/37/1/9.

Torres, L., McLeod, A., Yazbeck, B., Rayner, G., Skrbis, M., Yates, S., Dickson, N., \& Fulton, H. (2018). Digital skill development framework. Retrieved from https://www.monash.edu/_data/ assets/pdf_file/0010/1652437/DSD-22.05.20.pdf.

Vygotsky, L. S. (1978). Mind in society. Harvard University Press.

Wielenga-Meijer, E. G., Taris, T. W., Wigboldus, D. H., \& Kompier, M. A. (2011). Costs and benefits of autonomy when learning a task: An experimental approach. The Journal of Social Psychology, 151(3), 292-313.

Willison, J. (2012). When academics integrate research skill development in the curriculum. Higher Education Research \& Development, 31(6), 905-919. https://doi.org/10.1080/07294360.2012. 658760

Willison, J. (2017). The Models of Engaged Learning and Teaching (MELT). Retrieved from https:// www.adelaide.edu.au/melt/.

Willison, J, (2018) Research skill development spanning higher education: Critiques, curricula and connections. Journal of University Teaching and Learning Practice, 15(4). Retrieved from https:// ro.uow.edu.au/jutlp/vol15/iss4/1.

Willison, J. (2020). The models of engaged learning and teaching: Connecting sophisticated thinking from early childhood to PhD. Springer. https://doi.org/10.1007/978-981-15-2683-1.

Willison, J., \& Buisman-Pijlman, F. (2016). PhD prepared: Research skill development across the undergraduate years. International Journal for Researcher Development, 7(1), 63-83. https:// doi.org/10.1108/IJRD-07-2015-0018

Willison, J., Lievre, K., \& Lee, I. (2010). Making research skill development explicit in coursework. Prepared for the Australian Learning \& Teaching Council. Retrieved from https://www.adelaide. edu.au/melt/evidence\#empirical-studies-of-research-skill-development.

Willison, J., \& O’Regan, K. (2006/2018). Research skill development framework. Retrieved from https://www.adelaide.edu.au/melt/ua/media/51/rsd-framework.pdf.

Willison, J., \& O'Regan, K. (2007). Commonly known, commonly not known, totally unknown: A framework for students becoming researchers. Higher Education Research \& Development, 26(4), 393-409. https://doi.org/10.1080/07294360701658609

Willison, J., Sabir, F., \& Thomas, J. (2017). Shifting dimensions of autonomy in students' research and employment. Higher Education Research and Development, 36(2), 430-443. https://doi.org/ 10.1080/07294360.2016.1178216

Willison, J., Schapper, J., \& Teo, E. (2009, February 6). Multiple methods of improvement of research skills in business ethics and business law. Paper presented at QATLHEBEC Conference, University of Melbourne, Melbourne, Australia. Retrieved from https://www.adelaide.edu.au/ melt/ua/media/756/willison_schapper_teo.pdf.

Wong, T., \& Yahya, E. (2017, December 11-13). Towards a more cogent curriculum for experimental writing: A case study. Paper Presented at I-MELT (Models of Engaged Learning and Teaching) Conference, Adelaide, Australia. Retrieved from https://www.adelaide.edu.au/melt/ ua/media/300/wongimelt2017paper.pdf.

Zoghi, M., \& Dehghan, N.H. (2012). Reflections on the what of learner autonomy. International Journal of English Linguistics, 2(3), 22-26. Retrieved from http://citeseerx.ist.psu.edu/viewdoc/ download?doi=10.1.1.866.4252\&rep=rep1\&type=pdf. 
Lynette Torres is the Research and Learning Skills Lead at Monash University Library and has extensive experience designing learning approaches for stu-dents' research skill development for secondary and higher education sectors. Lyn is passionate about invigorating learning by making skill development a visible and explicit part of teaching and curriculum de-sign. She instigated and led the library's implementation of the Models of Engaged Learning and Teaching (MELT) to catalyse library-faculty partnerships for the in-curricular development of students' research, work and digital skills. Lyn is active in the educational research com-munity, facilitated MELT workshops nationally and internationally, published articles, presented at conferences and participated in nation-ally funded research. Recipient of three Monash University Excel-lence in Learning and Teaching awards, and the CAUL (Council of Australian University Librarians) Achievement Award.

Barbara Yazbeck has experience teaching a range of academic literacies in a higher edu-cation setting. She has an interest in critical pedagogies that develop critical, creative thinkers with strong reasoning skills, who can apply knowledge, information and research skills to complex problems in a range of contexts, and are effective oral and written communicators. She was awarded a citation for 'Excellence in developing evidence-based medicine curricula, based on world's best practice that engages students in inquiry-driven learning and practice for life'. She has been working with the MELT frameworks since 2013.

Open Access This chapter is licensed under the terms of the Creative Commons Attribution 4.0 International License (http://creativecommons.org/licenses/by/4.0/), which permits use, sharing, adaptation, distribution and reproduction in any medium or format, as long as you give appropriate credit to the original author(s) and the source, provide a link to the Creative Commons license and indicate if changes were made.

The images or other third party material in this chapter are included in the chapter's Creative Commons license, unless indicated otherwise in a credit line to the material. If material is not included in the chapter's Creative Commons license and your intended use is not permitted by statutory regulation or exceeds the permitted use, you will need to obtain permission directly from the copyright holder.

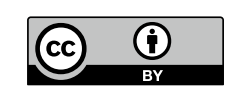

